RODRIGO REZENDE AMARAL ${ }^{1}$

E-mail: Rodrigo.RezendeAmaral@ UGent.be

IVANA ŠEMANJSKI, Ph.D.2

(Corresponding author)

E-mail: Ivana.Semanjski@fpz.hr

SIDHARTA GAUTAMA, Ph.D. ${ }^{3}$

E-mail: Sidharta.Gautama@UGent.be

EL-HOUSSAINE AGHEZZAF, Ph.D. ${ }^{1}$

E-mail: ElHoussaine.Aghezzaf@UGent.be

${ }^{1}$ Ghent University, Faculty of Engineering and Architecture

Department of Industrial Systems Engineering and

Product Design

Technologiepark 903, 9052 Zwijnaarde, Belgium

2 University of Zagreb

Faculty of Transport and Traffic Sciences

Vukelićeva 4, 10000 Zagreb, Croatia

${ }^{3}$ Ghent University, Faculty of Engineering and Architecture

Department of Telecommunications and Information

Processing

St-Pietersnieuwstraat 41, B-9000 Gent, Belgium
Transport Logistics

Preliminary Communication

Submitted: 19 Nov. 2017

Accepted: 20 Sep. 2018.

\title{
URBAN MOBILITY AND CITY LOGISTICS - TRENDS AND CASE STUDY
}

\begin{abstract}
Improving urban mobility is crucial to the sustainable development of a city. Well-managed movement of individuals, goods, and services is essential to increase citizens' welfare, not only by reducing travel times and congestion levels, but also by minimizing air pollution, noise, accidents, etc. To achieve the desired results, the objectives and scope of the optimization efforts have become broader in recent years. Instead of focusing only on the flows and on the network itself, research and projects have connected various areas of economy to traffic management, such as public health and logistic optimization. In this work we discuss the interconnections between urban mobility and city logistics, and present a case study showing how the mobility plan implemented in Ghent (Belgium) in April 2017 affected its logistic system.
\end{abstract}

\section{KEY WORDS}

urban mobility; city logistics; urban freight; traffic management; network assignment models;

\section{INTRODUCTION}

Urban mobility has been in the focus of transportation research for decades. Along these years, several concerns have been debated. At first, mobility side effects such as travel times, costs, and congestion had attracted attention as they immanently reflect on individuals' and communities' economic success. Later, more attention was gradually devoted to other issues, such as road safety and air and noise pollution, since they strongly impact the urban quality of life and the global environment [1]. However, a common denom- inator in all of these discussions is the generally accepted notion that reducing the number of motorized vehicles and the time that they spend in the network is a goal to be pursued [2]. Improved mathematical techniques and technology, supported by observation and empirical analysis, enable continuous improvement of solutions proposed in traffic and transport management to achieve this goal.

The present-day approach to dealing with mobility challenges mirrors an economic belief prevalent in most developed countries: externalities should be avoided. An externality is the cost or benefit that affects a party who did not choose to incur that cost or benefit. This is the case of congestion and other nuisances created by traffic. By internalizing the economic and social costs of network use (i.e., by penalizing the parties responsible for nuisances and/or rewarding those who follow a desired behavior), decisions of all stakeholders are expected to become aligned with the traffic policy's goal. In other words, if the amount paid by all network users reflects both private and social costs, they are supposed to make a more rational use of the network. The invisible hand of the market would bring the equilibrium to a more equitable point (Figure 1), which would conceivably result in a lower global cost. Strategies for the internalization of costs include subsidies and promotion of public transport, congestion pricing, parking management, higher license and emission taxes, incentives to commuters who cycle or use alternative transportation means to go to work, etc. 


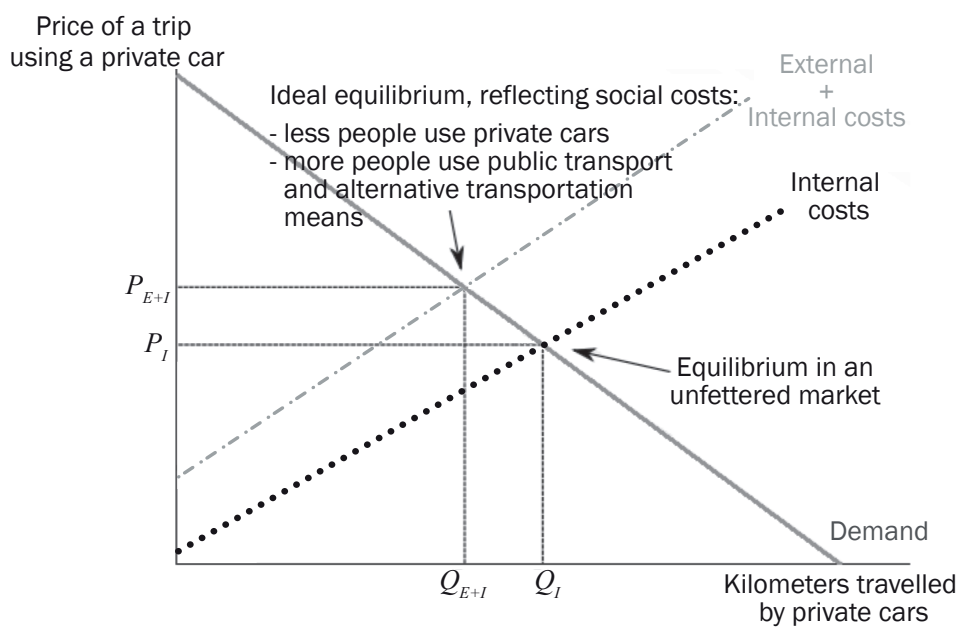

Figure 1 - Market equilibrium with and without externalities

However, it should be considered that transport is not an end in itself but the means by which people are able to engage in activities that require people themselves and material goods to be in different places at different times [3]. There are many stakeholders involved in this process, and the complete decision chain constitutes a multilevel optimization structure. Consequently, the equilibrium does not necessarily lie on the lowest cost point. The sets of rules that govern the decisions of the stakeholders may strongly differ, and they are not always in harmony with the transport policy purposes. To ensure better results, traffic managers must examine the decision-making processes carried out by each network user in order to anticipate their actions, and use this information to redesign the system and address their specific needs. Unfortunately, due to the traditional top-down implementation of traffic management systems, this happens less frequently than desired.

While the circulation of private cars in urban areas is being discouraged and overpriced in an attempt to shift people towards more sustainable transport modes, new solutions must be studied for the urban logistics segment. Unlike commuters, logistic operators do not use the transportation network to move from one point to another in the city, but to distribute their goods or provide their services. Their objective is not to minimize travel times or costs, but to maximize their profits. And, finally, their scope of action is wider than the route choice. They may adapt the number and the capacity of their vehicles; the location and the dimension of their warehouses; the frequency and the order in which customers are served; the inventory management policies, etc. These dissimilarities result in different responses to the transport policy measures and to changes on the network supply.

To illustrate why it must be taken into account in transport policies, let us consider what happens when private cars are banned from some streets and lanes in order to prioritize public transport. Since car trips become longer and costlier, some commuters and car users are expected to change their transportation mode and shift towards other available options. As desired by urban mobility decision makers, this contributes to the reduction of the number of cars and the time they spend in the network. Logistic operators, however, usually do not have an alternative to deliver their goods or services. Their vehicles will need to travel more, and possibly more vehicles will be needed to accomplish all deliveries. Although these extra costs (which will ultimately be passed on to the end customers, i.e., citizens) can be seen as an internalization of the congestion costs, there is no contribution to the transport policy's goal or to the minimization of the global costs. The economics behind this lose-lose situation is depicted in Figure 2.

This analysis does not intend to suggest that prioritizing public transport is a wrong strategy or that the increase in the number of logistic vehicles and in the distance travelled by them exceeds the reduction of those by ordinary users. The message is that different solutions should be devised for different user classes. In the same way that public transport networks have been studied, planned, and developed for the sake of providing alternatives to ordinary users, further improvements can be achieved if more attention is given to the urban logistic network. The concept of city logistics was developed to explore this opportunity. City logistics is defined as the process for totally optimizing the logistics and transport activities by private companies with support of advanced information systems in urban areas considering the traffic environment, the traffic congestion, the traffic safety and the energy savings within the framework of a market economy [4]. Three elements are essential for promoting city logistics: (1) the application and innovation of information 


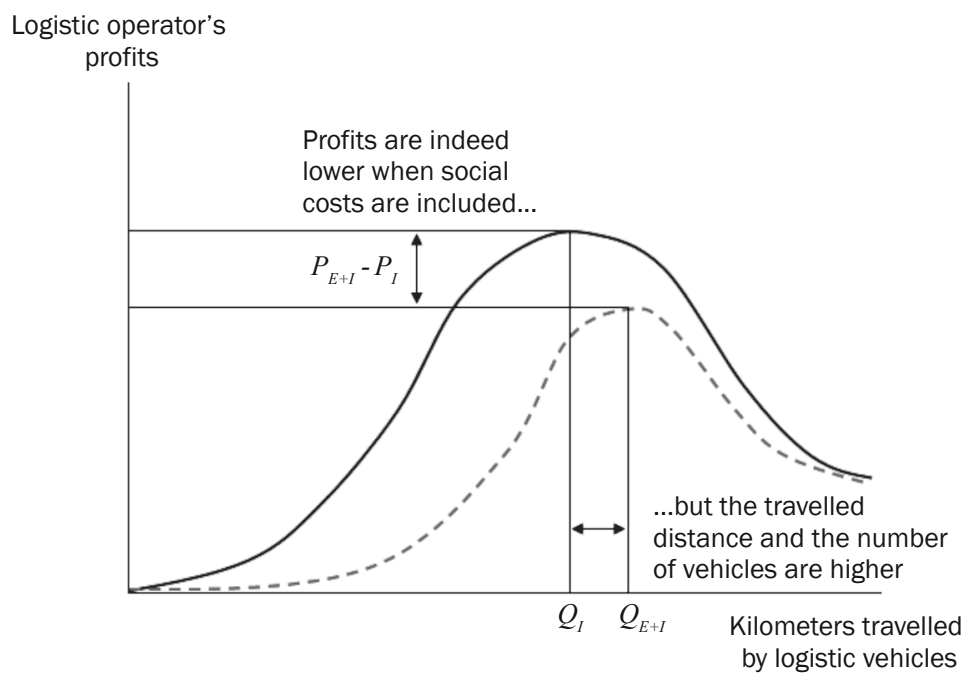

Figure 2 - Logistic operators do not minimize costs. Instead, they maximize profits

and communication technology (ICT) and intelligent transport systems (ITS), (2) change in mind-sets of logistics managers, and (3) public-private partnerships.

In this paper, we present a review of the evolution, trends, and interconnections between urban mobility and city logistics (Section 2). This is followed by an illustrative example of a real-life case study situated in the city of Ghent, Belgium, were a new mobility plan was implemented in April 2017. This change in an urban mobility system serves as a test bed for analysis of potential benefits that synergy between impacts of new measures for urban mobility and city logistics can bring, as well as to highlight the opportunities to enhance the current state of urban transport policies (Section 3).

\section{EVOLUTION AND TRENDS IN URBAN MOBILITY AND CITY LOGISTICS}

When cities initially faced a substantial increase in the number of vehicles and the resulting congestion levels, first attempts to solve or mitigate the problem involved infrastructural measures such as enlarging the streets and expanding the road network. This predict-and-provide approach was later abandoned [5], and more holistic and multidisciplinary approaches were considered, including the economic one. From these broader perspectives, the mentioned solution underestimated the latent demand [6]. By building new roads and presumptively suggesting the reduction of congestion levels, policy-makers gave the population the sign that travelling by car was the right thing to do. This induced more and more people to enter the network with their privately owned vehicles, and their number rose above any expectations. From 1980 to 2000, 1.2 more automotive vehicles were added to the vehicle population of the United States for each person added to the human population. And, more importantly, the total vehicle miles travelled grew 80 percent because of the more intensive use of each vehicle [7]. The growth of the automotive industry undoubtedly had a positive impact on the economic development of most countries [8]. In 2009, the U.S. motor vehicle manufacturing industry employed 880,000 workers, or approximately $6.6 \%$ of the U.S. manufacturing workforce [9]. This has certainly influenced the traffic policies and associated decisions taken by the governments too, and may explain why the road expansion strategy prevailed for a long time. At a certain point, however, the congestion levels and costs became unbearable, and traffic management and optimization oriented solutions emerged, including the ITS [10]. Furthermore, investments and promotion of public transport were established as the main pillar of urban mobility, which later included the use of alternative means of transportation [11].

In more recent years, monetary incentives for commuters who cycle to work were implemented in some countries. Those subsidies can allegedly be paid back by savings in the health care system [12]. Incentives for car sharing and carpooling [13], for peak hour avoidance [14], and for companies which hire people to work from home are other examples of measures being taken to reduce traffic [15]. These measures show that the solutions for traffic problems do not necessarily have to be centered on improvements to the transportation network itself, but, instead, may be connected to other areas of economy. The development of models to evaluate the impact of these measures is gaining importance [16-18].

Since these investments and incentives are too expensive and often not enough to change people's habits and transportation choices, disincentives and penalties are designed to lessen unwanted behaviors such as the use of private cars in dense urban regions. These measures encompass road space rationing 
[19], restrictions and prohibitions, congestion pricing [20], revenue-neutral credit-based mobility rights [21]; overpriced parking and toll fees; higher license and emission taxes; etc. Parking areas in companies, offices, and residential buildings are also being targeted and overtaxed in some cities.

Underestimation of latent demand occurred in the past, at least partially, because the decision-making process of carless people was not fully considered. These network users might have preferred to use public transport or other transportation means if these alternatives were made available and focused, instead of spending their money on a car to stand still in traffic jams. Most traffic management experts agree that not providing these alternatives was a mistake, and this is currently being redressed by the measures and policies mentioned [22-23]. These efforts, however, may have serious impacts on urban logistics. If the decision-making process of logistic stakeholders is not taken into account, suboptimal traffic policies and networks are likely to be created again. Alternatives for these network users must be studied and implemented, and this is one of the aims of the city logistics research.

Taniguchi [24] summarizes the concepts of city logistics, and recent trends and gaps were compiled by Taniguchi et al. [25] and Anand et al. [26]. In this last work, the authors selected 30 relevant works on urban freight modelling and classified them according to stakeholder, objective, descriptor, and perspective. The vast majority of them had "efficiency" listed as main objective, and "(logistic) planner" as perspective. This indicates that city logistic works are often directed to enhancing the distribution strategies implemented by logistic operators. The traffic network and policies are mostly deemed as fixed constraints.
Nevertheless, there are works which discuss urban logistics and traffic policies. Cochrane et al. [27] consider the possibility of moving freight on public transit. Freight on transit (FOT), as it is referred to, is an operational strategy in which public transit vehicles and/ or infrastructure are used to move freight. Although this strategy is relatively common and well-established in maritime, rail, and air freight transport, it is not yet spread in cities. Some recent projects have already attempted to implement FOT solutions, such as cargo trams on light rail tracks. This has been successfully done in Dresden by CarGoTram [28], but has failed in Amsterdam with City Cargo [29]. The resurgence of bus rapid transit (BRT) [30] may also provide an opportunity if segregated busways could be used for freight transport.

In the next section we analyze the transportation network of the city of Ghent, in Belgium, from the urban mobility and logistics perspectives. Based on the literature review presented in this section, we discuss the mobility plan which was introduced in this city in April 2017.

\section{STUDY CASE: THE TRANSPORTATION NETWORK IN GHENT, BELGIUM}

The city of Ghent (Figure 3 ) is the capital and largest city of the East Flanders province. After Antwerp, it is the largest municipality of Belgium [31]. It is located at the confluence of the Scheldt and Leie rivers about 50 kilometers west of Brussels (the capital of Belgium) and is connected with the North Sea by the Ghent-Terneuzen Canal, which makes the city a major port of Belgium. Ghent has almost 260,000 inhabitants and is home to one of the largest universities in Belgium (Ghent University) with over 41,000 students [32]. The municipality comprises the city of Ghent proper and the thirteen surrounding towns (Afsnee, Desteldonk, Drongen,

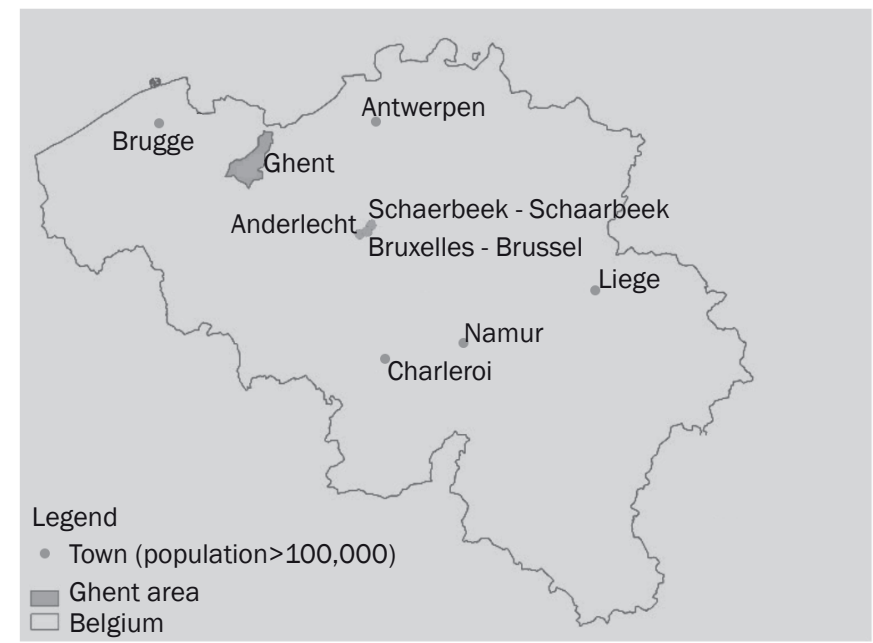

a)

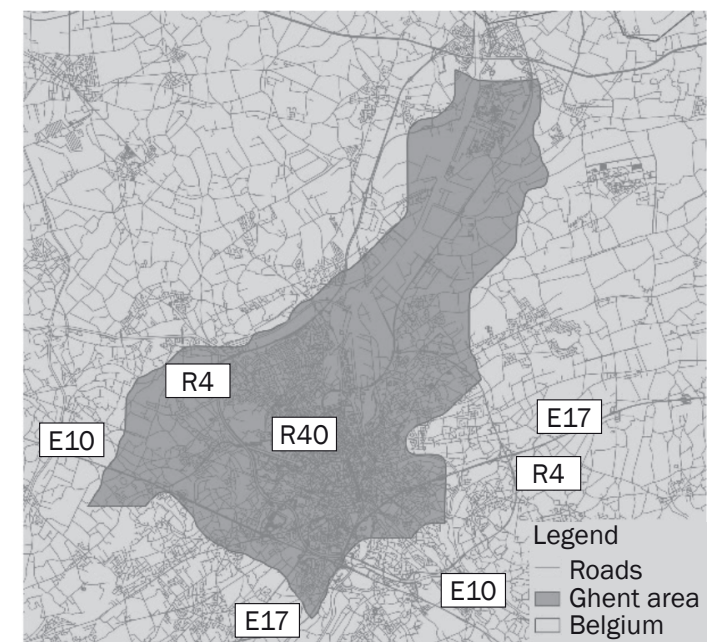

b)

Figure 3 - a) Belgium, b) City of Ghent 
Gentbrugge, Ledeberg, Mariakerke, Mendonk, Oostakker, Sint-Amandsberg, Sint-Denijs-Westrem, SintKruis-Winkel, Wondelgem, and Zwijnaarde).

Ghent is surrounded by two very busy ring roads. The R4 connects the outskirts of Ghent with each other and the surrounding towns, and also leads to the main motorways. The second, inner ring road R40 connects the different downtown quarters with each other. By car, the city is accessible via two motorways, the E40 road (connects Ghent with Bruges and Ostend to the west, and with Brussels, Leuven, and Liège to the east) and the E17 (connects Ghent with Sint-Niklaas and Antwerp to the North, and with Kortrijk and Lille to the South). The rail network includes two train stations. The international railway station Gent Sint-Pieters is situated in the south part of the city and the intercity railway station Gent Dampoort is located in the northeast part of the city. Ghent is also a home to the largest designated cyclist area in Europe, with nearly 400 kilometers of cycle paths, more than 700 one-way streets (where bicycles are allowed to go against the traffic [33]), and with over 51 hectares of car-free or low-traffic areas [34]. The public transport network includes 56 bus and five tram lines [35] with a commercial speed of $16 \mathrm{~km} / \mathrm{h}$ [34]. Geographically, Ghent is located on rather flat ground, which makes it convenient for active transport modes like cycling and walking. Thus, its mobility system is characterized by a large share of cycling (30\% modal share) and over 50\% modal share of sustainable transport modes (bicycle, foot, public transport) [34]. The average household in Ghent owns 2.8 bicycles and 1.2 cars. In addition, $7.7 \%$ of households are car share users, while $12 \%$ of them do not own a car. Hence, Ghent has a dynamic and diverse network with well-connected transport modes that reflects in over 650,000 trips per day [31].

\subsection{The mobility plan implemented in 2017: Het Circulatieplan}

The mobility plan implemented in 2017 in Ghent under the name Het Circulatieplan (freely translated from Dutch as "The Circulation Plan") aims to improve the well-being of inhabitants and visitors while providing accessibility for cyclists, buses, trams, and cars in the city.

In order to prevent car drivers from crossing the inner city unnecessarily and provide more space and safety for pedestrians, cyclists, buses, and trams, the city was divided into 6 sectors and one central car-free zone. Cars are not allowed to use the inner streets to go from one sector to another. They must use the ring road (R40). Emergency services, waste collection vehicles, healthcare providers, buses, taxis, trams, and bicycles may still use inner streets to go from one sector to another in most cases. In some situations, they may also drive in car-free zones, which mostly happens with the tram network. A few streets were defined as pedestrian streets and their access is forbidden for all vehicles, including bicycles, every day between 11 a.m. and 6 p.m. To ensure that a driver could always reach the ring without changing sectors, a few oneway streets had their driving directions changed. CCTV cameras with number plate recognition capabilities facilitate the enforcement of the new rules. In the first months after the mobility plan was implemented, a single offence would not generate a fine.

Other measures were also part of the mobility plan, such as the increase of parking restrictions and fees, and the enhancement and promotion of park-and-ride areas in the outskirts of the city.

The sectors are shown in Figure 4. Some routes which were previously allowed are displayed in yellow, and the corresponding routes in the current situation are shown in red.

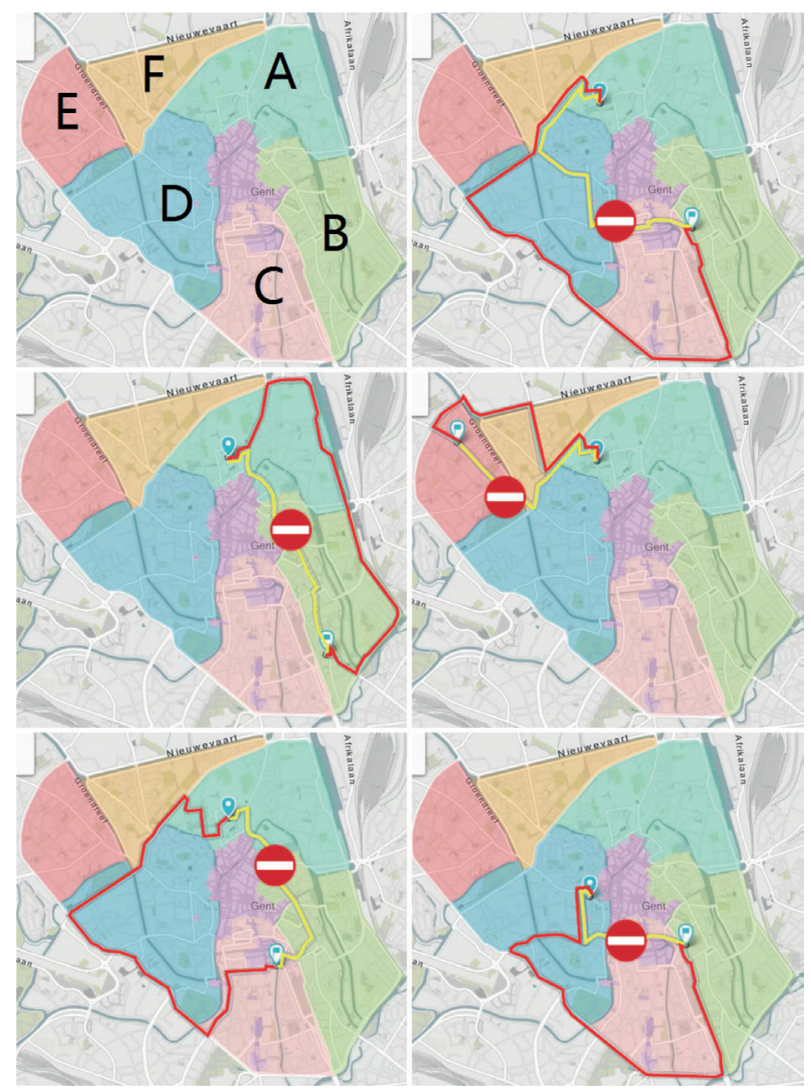

Figure 4 - Ghent's Circulation Plan

\subsection{The logistic network}

In order to evaluate the impact of the mobility plan on the routes of logistic vehicles and explore opportunities to improve the current state, we examined the case of companies that deliver products to pharmacies. Sixteen major pharmacies from all zones in the city and a supplier located in a nearby submunicipality were selected. They are listed in Table 1 and shown on the map in Figure 5. 


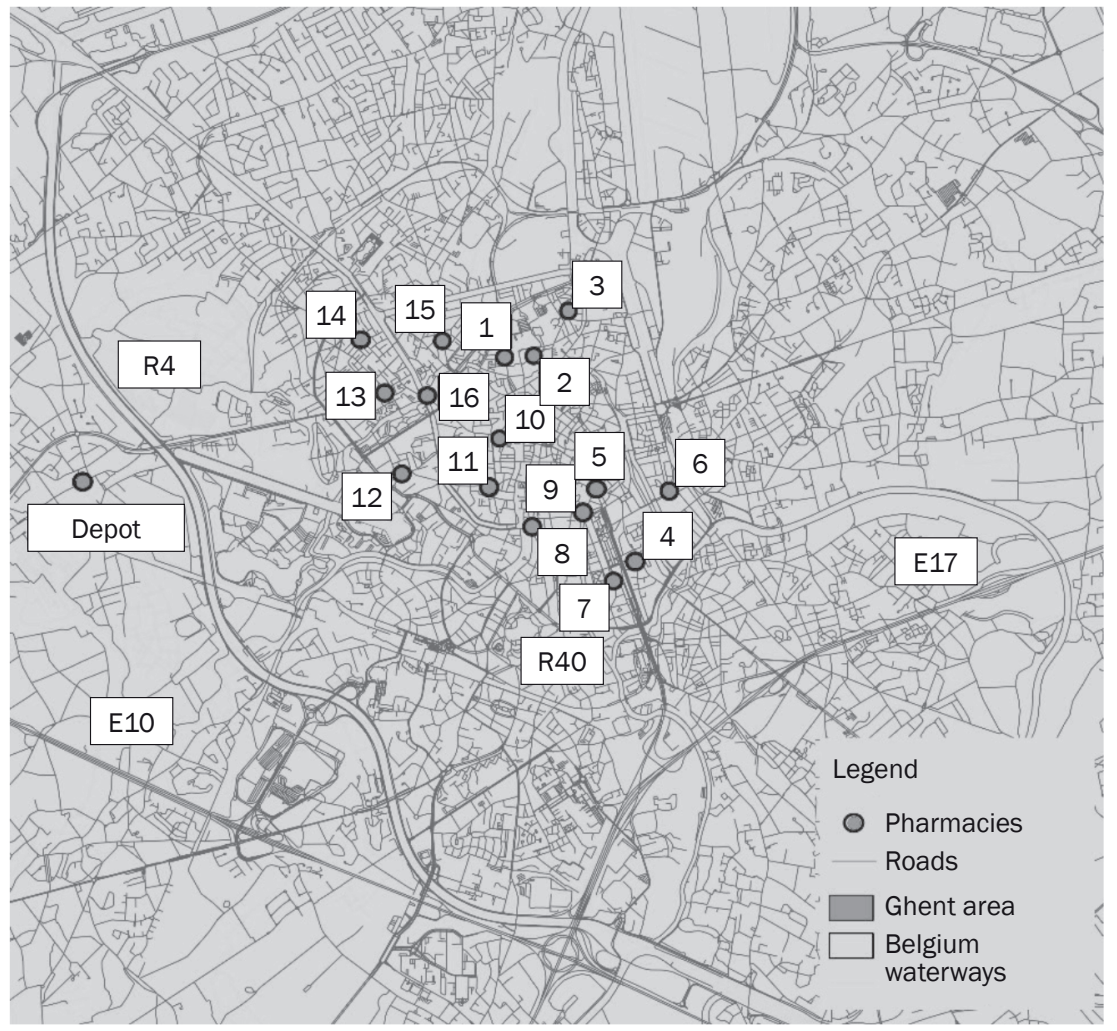

Figure 5 - Case study: delivering to pharmacies

Table 1 - List of pharmacies: zone, name and address

\begin{tabular}{|r|l|l|l||}
\hline \multicolumn{1}{|c|}{ Zone } & \multicolumn{1}{|c||}{ Name } & \multicolumn{1}{c||}{ Address } \\
\hline \hline 1 & A. Tolhuis & Apotheek Erika Lox & Meelstraat 2, 9000 Gent \\
\hline 2 & A. Tolhuis & CoOP - Apotheek - Kathleen Martin & Dobbelslot 2, 9000 Gent \\
\hline 3 & A. Tolhuis & Apotheek Tolhuis BVBA & Tolhuislaan 142, 9000 Gent \\
\hline 4 & B. Portus Ganda & Apotheek Callebaut BVBA & Clarissenstraat 1, 9000 Gent \\
\hline 5 & B. Portus Ganda & Apotheek Brabantdam & Brabantdam 73, 9000 Gent \\
\hline 6 & B. Portus Ganda & Apotheek Denys & Kasteellaan 74, 9000 Gent \\
\hline 7 & C. Krook & Apotheek Leveugle & F. Rooseveltlaan 505, 9000 Gent \\
\hline 8 & C. Krook & Apotheek De Cuyper / Catherine & Nederkouter 123, 9000 Gent \\
\hline 9 & C. Krook & Apotheek De Belie NV & Lammerstraat 37, 9000 Gent \\
\hline 10 & D. Coupure & Apotheek Cattebeke & Sint-Michielsstraat 15, 9000 Gent \\
\hline 11 & D. Coupure & Apotheek Van Der Linden & Annonciadenstraat 21, 9000 Gent \\
\hline 12 & D. Coupure & Apotheek Aerts-De Marteleire / M. & Ekkergemstraat 56, 9000 Gent \\
\hline 13 & E. Brugse Poort & Apotheek Brugse Poort & Kettingstraat 94, 9000 Gent \\
\hline 14 & E. Brugse Poort & Buyse Apotheek NV & Bevrijdingslaan 154, 9000 Gent \\
\hline 15 & F. Rabot & Apotheek Rabot & Wondelgemstraat 87, 9000 Gent \\
\hline 16 & F. Rabot & Apotheek Spiers & Noordstraat 38, 9000 Gent \\
\hline 17 & Depot & (Anonymous supplier) & Oude-Abdijstraat 100, 9031 Drongen \\
\hline
\end{tabular}

In our formulas, we refer to the number of pharmacies as $N$. The depot is the start and the end point of every route. The set of pharmacies plus the depot is denoted by $C$. To calculate the routes, we consider the transportation network available for private cars before and after the implementation of the mobility plan.
These two scenarios are respectively indicated in the formulas by $h=1$ and $h=2$. The difference in the logistic costs between the two scenarios may be seen as the cost of the mobility plan to the logistic operator, and, to some extent, it is also an estimation of how much they would be willing to pay to use the old network, 
which is mostly still available for waste collection vehicles, healthcare providers, buses, and taxis. With a few exceptions, this network is very similar to $h=1$, since vehicles are still allowed to use the inner streets.

For each network scenario $h$ and for each combination $m$ of $k_{m}$ pharmacies $\left(k_{m} \in 2 \ldots N\right)$ we calculated the shortest route, which starts and ends at the depot and includes all pharmacies in the combination. The length of such route is denoted by $\delta_{m}(h) . C(m)$ is used to denote the set of pharmacies in the combination $\mathrm{m}$ plus the depot, and $\delta_{i j}(h)$ is the distance between two pharmacies, between a pharmacy and the depot, or between the depot and a pharmacy (i.e., i.j $\in C$ ) in the scenario $h$. The calculation of $\delta_{m}(h)$ can be expressed as an instance of the travelling salesman problem (Equations 1a-1e).

$$
\begin{aligned}
& \delta_{m}(h)=\min \sum_{i \in C(m)} \sum_{j \in C(m)} \delta_{i j}(h) \cdot x_{i j} \\
& \text { s.t. } \sum_{j \in C(m), j \neq i} x_{i j}=1 \quad \forall i \in C(m) \\
& \text { s.t. } \sum_{j \in C(m), i \neq j} x_{i j}=1 \quad \forall j \in C(m) \\
& u_{i}-u_{j}+(|C(m)-1|) x_{i j} \leq|C(m)|-2 \quad \forall i, j \in C(m)_{i \neq j} \\
& x_{i, j} \in\{0,1\} \quad \forall i \in C(m), \forall j \in C(m)
\end{aligned}
$$

The binary decision variables $x_{i, j}$ assume the value 1 if the shortest route includes the link between $i$ and $j$, and 0 otherwise. The sets of constraints $1 b$ and $1 c$ ensure, respectively, that only one link is used to depart and to arrive in each node, while the Miller-Tucker-Zemlin subtour elimination constraints $1 d$ ensure that only one path connects all points. The auxiliary variables $u_{i}^{l}$ are added to formulate these constraints.

In order to compare the scenarios from the logistic perspective, we calculated the average length of the routes having the same number of pharmacies $k$ for each scenario $h$. This value is denoted by $\overline{\delta_{k}(h)}$. If $M$ is the set of all combinations $m$, we can define $M(k)$ as the subset of combinations having $k$ pharmacies $\left(M(k)=m \in M \mid k_{m}=k\right)$. The cardinality of $M(k)$, i.e., the number of combinations having $k$ pharmacies, is $|M(k)|=\left(\begin{array}{c}N \\ k\end{array}\right)=\frac{N !}{k !(N-k) !}$. The calculation of $\overline{\delta_{k}(h)}$ is expressed by Equation 2a.

$$
\overline{\delta_{k}(h)}=\frac{\sum_{m \in M(k)} \delta_{m}(h)}{|M(k)|}
$$

Because $\overline{\delta_{k}(h)}$ contains the trips from the depot to the first pharmacy and from the last pharmacy to the depot in every route, we consider that it is suitable to subtract two times the distance from the depot to the city's ring from this value to obtain a better approximation of the average in-city tour length (since all pharmacies are inside the ring). A graph comparing the result in each scenario is displayed in Figure 6. As expected, the average length of the routes no longer comprises the same number of points after the implementation of the mobility plan.

Using the typical off-peak travel times between every pair of points, we could calculate the expected duration of the tours in each scenario. The results are displayed in Figure 7. This part of the analysis is especially important from the logistic point of view to estimate the fleet and labor costs (i.e., how many vehicles and how many driving hours are needed to fulfil the demand). Depending on the type of constraints and cost structure which a logistic operator faces, different perspectives can be evaluated (e.g. how many customers can be visited in a certain time frame or how much time is needed to visit a certain number of customers).

The difference between the average tour durations is proportionally much greater than the difference between the lengths. Tours consisting of 4 customers take almost three times longer after the implementation of the mobility plan, and tours consisting of 12

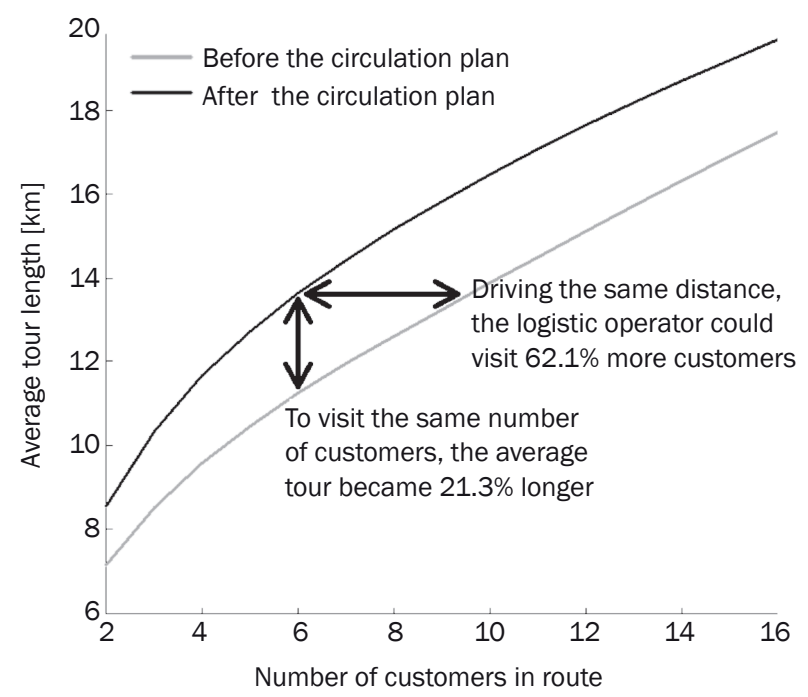

Figure 6 - Average tour length vs number of points in tour

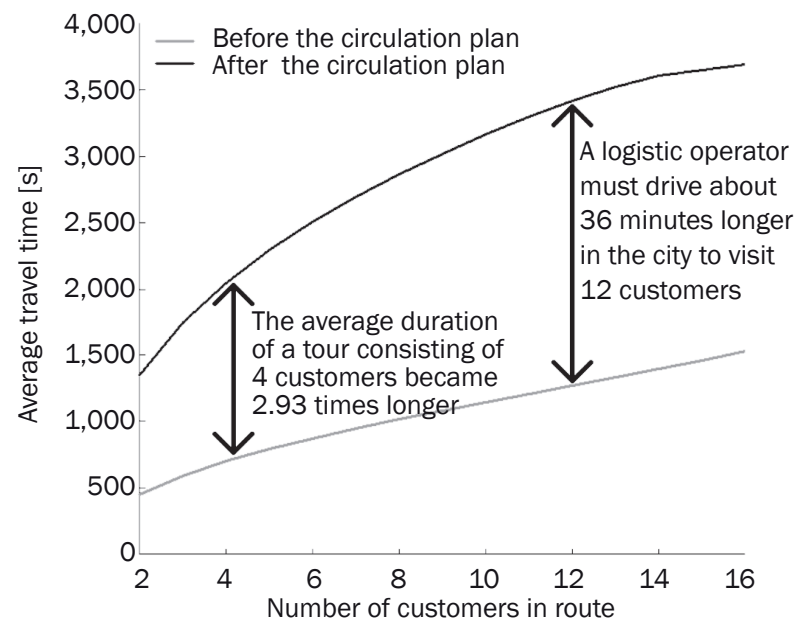

Figure 7 - Average tour duration vs number of points in tour 
customers take about 36 minutes longer in off-peak hours. These results would certainly be even worse if rush hours were considered. The differences are very significant when we consider that the radius of the inner city, i.e., the distance between the center and the inner ring, is only $2 \mathrm{~km}$ approximately.

This is explained by the fact that logistic operators must drive multiple times from the ring to the center and vice-versa, and these legs are often travelled in very narrow and busy streets. Also, since more traffic is shifted to the ring, travelling there became slower as well. Figure 8 illustrates it with a worst-case scenario, i.e., when the customers are in different zones.

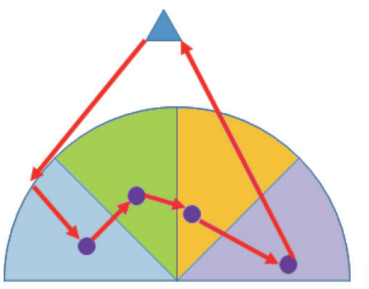

Before

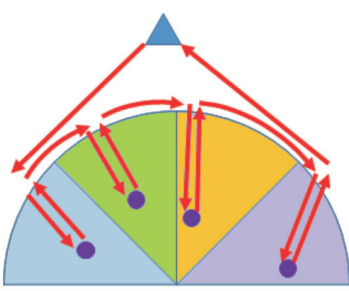

After

Figure 8 - Illustration of a worst-case scenario

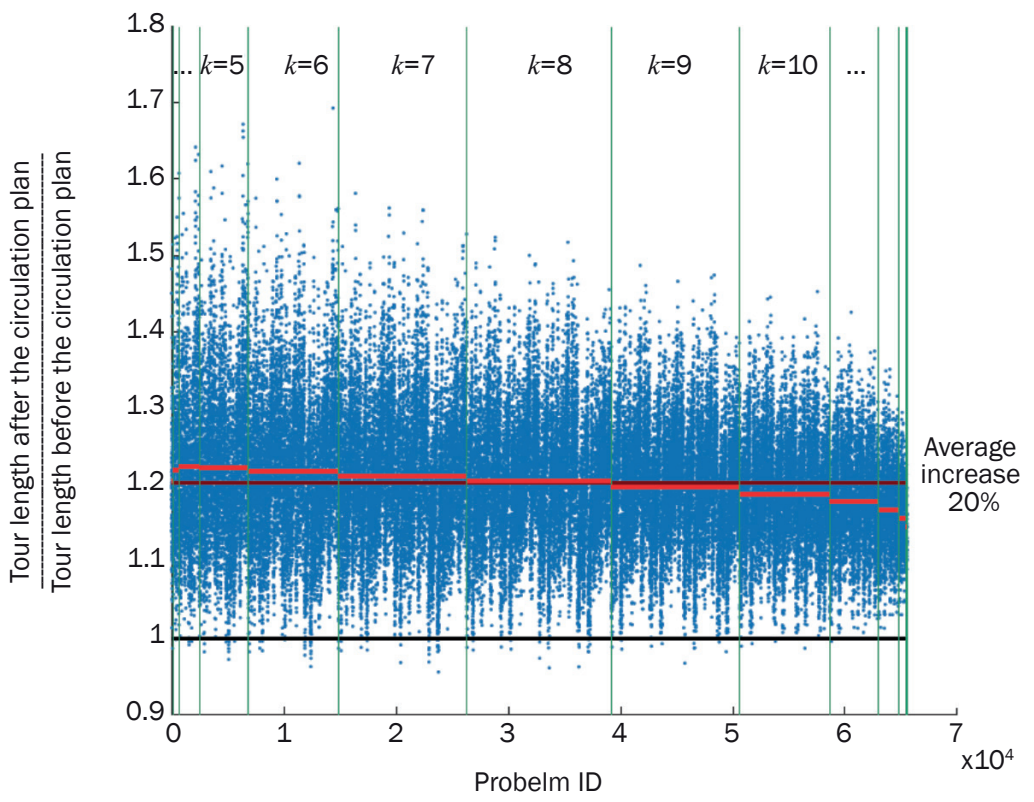

Figure 9 - Relative increase in the tour length by number of customers

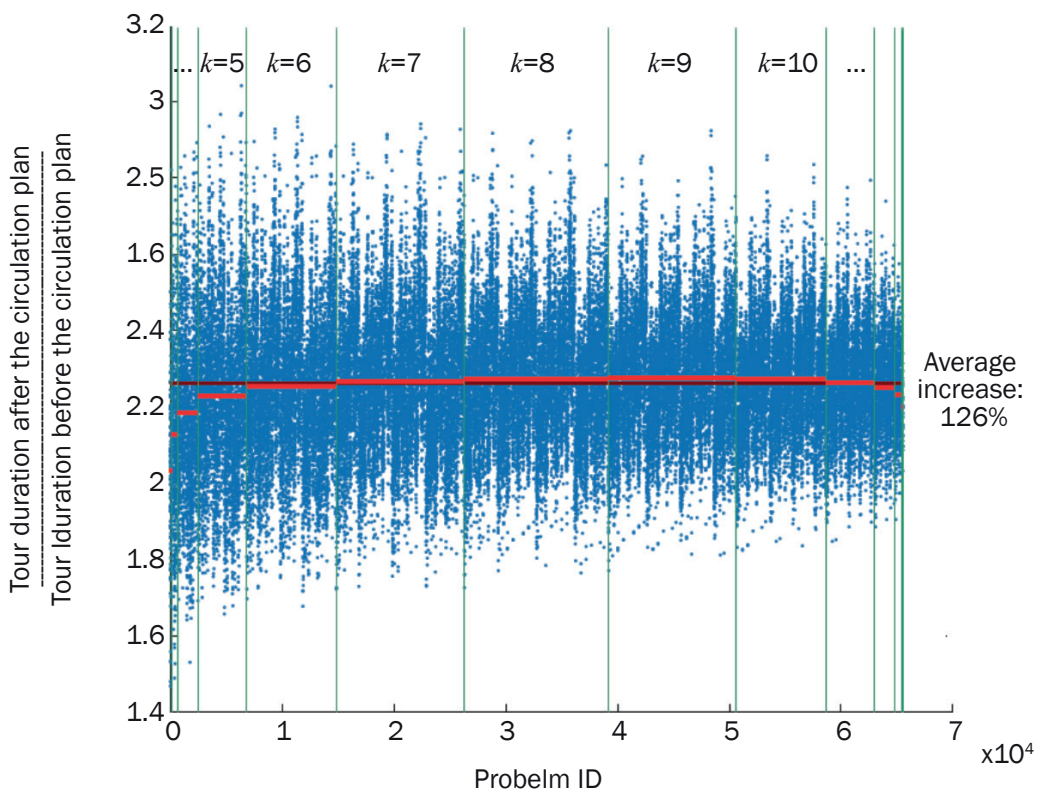

Figure 10 - Relative increase in the tour duration by number of customers 
In some exceptional cases, the tour length after the implementation of the mobility plan was reduced, because some streets had their driving directions changed to facilitate the access to the ring from within each zone. This, however, is not necessarily translated into a shorter travel time.

In order to verify the relation between the increase in the tour length and the number of customers, we calculated the ratio of the lengths after and before the mobility plan for all combinations of customers. This allowed us to calculate the average increase for routes with the same number of customers and compare it to the global average. The results are presented in Figure 9. The global average increase is about $20.3 \%$. Although the averages are slightly higher for tours with less customers, the difference would not be relevant in the calculation of logistic costs.

The same analysis was made for the increase in the tour duration. The results are presented in Figure 10. The global average increase is $126.2 \%$. Contrarily to the tour lengths, the increase grows with the number of customers in the routes. Generally speaking, the difference would also not be relevant in the calculation of logistic costs, but there is an interesting fact to be observed. The duration of tours with two to four customers had a considerably lower increase compared to the others. It means that logistic operators which usually have more than four customers in their routes were proportionally more affected than commuters who must travel between two points in the city.

\section{CONCLUSIONS}

There is a big potential to improve urban traffic by including the logistic point of view in the analysis, optimization models, and mobility plans. One of the possibilities is to allow freight vehicles to use part of the public transport infrastructure, as taxis do. It may reduce congestion and pollution, while improving the logistic performance of the network. In order to verify the economic feasibility of this idea, it is necessary to know how much logistic operators' costs would decrease and how much the city could benefit from it. The case study presented in this paper is an attempt to answer the first question, based on the Ghent situation. However, a straightforward conclusion cannot be easily drawn, since the topic involves major practical and political discussions. Questions on how it should be implemented and regulated, which companies would be eligible, etc., must be evaluated. The general public opinion has to be carefully considered too. Some people might not agree that private (delivery) vehicles should be allowed to use streets and lanes in which they are forbidden to drive. This triggers the study of conditions and measures to foster the acceptance of the proposed idea. The logistic operators can be charged fees and the revenue could be used to improve public transport or to subsidize other mobility projects. Extra restrictions can be applied, such as only allowing clean vehicles in the public transport network, and its use can be restricted to non-peak hours. This last condition takes advantage of an economic surplus, since the network supply is usually above the demand when the traffic is low (i.e., fewer buses in comparison to the peak hours use the same lanes). It can help balancing the supply and demand over time in the whole network, with the logistic operations being shifted from peak to non-peak hours. From the logistic operators' point of view, having the possibility to use the public transport infrastructure extends the feasible region for the logistic optimization. Even with the extra restrictions and costs as those above mentioned, the net contribution to their profits - and to the whole society, when the services and goods become cheaper - can make the idea attractive.

\section{RODRIGO REZENDE AMARAL}

E-mail: Rodrigo.RezendeAmaral@ UGent.be

IVANA ŠEMANJSKI, Ph.D.

E-mail: Ivana.Semanjski@fpz.hr

SIDHARTA GAUTAMA, Ph.D.

E-mail: Sidharta.Gautama@UGent.be

EL-HOUSSAINE AGHEZZAF, Ph.D.

E-mail: ElHoussaine.Aghezzaf@UGent.be

\section{TENDÊNCIAS EM MOBILIDADE E LOGÍSTICA URBANA: UMA REVISÃO DA LITERATURA E UM ESTUDO DE CASO SOBRE A CIDADE DE GHENT, BÉLGICA}

\section{ABSTRATO}

As relações simbióticas entre mobilidade, sistemas de logística, segurança viária e desenvolvimento sustentável nas redes de transporte urbano constituem um tópico relevante para a pesquisa em gestão de tráfego. Indivíduos viajariam mais rápido se o transporte de carga fosse excluído das cidades, mas isto reduziria sua ativadade e crescimento econômico. Da mesma forma, um ambiente perfeitamente seguro e livre de poluição exigiria o menor tráfego possível, mas isso significaria menos mobilidade e serviços, o que não se configura como uma solução sustentável. Este artigo concentra-se na discussão sobre as interconexões entre mobilidade e sistemas de logística urbanos. Uma revisão das tendências nestes tópicos é apresentada, fornecendo as bases para uma análise do plano de mobilidade implementado na cidade de Ghent, Bélgica, em abril de 2017. O foco deste estudo de caso são os impactos na rede de distribuição logística. As observações teóricas e empíricas feitas durante a pesquisa indicam que os planos de mobilidade poderiam ser melhorados se conceitos de otimização logística como o roteamento de veículos fossem levados explicitamente em conta, e não apenas como fluxos de rede agregados.

\section{PALAVRAS-CHAVE}

mobilidade urbana; sistemas de logística urbana; gestão de tráfego; 


\section{ACKNOWLEDGMENT}

This research work was partially supported by the CAPES Foundation (Proc. $n^{\circ}$ 9369-13-9), Ministry of Education of Brazil, Brasília - DF 70040-020, Brazil

\section{REFERENCES}

[1] Gillis D, Semanjski I, Lauwer D. How to Monitor Sustainable Mobility in Cities? Literature Review in the Frame of Creating a Set of Sustainable Mobility Indicators. Sustainability. 2016;2016(8): 20.

[2] Fuller D, Morency P. A Population Approach to Transportation Planning: Reducing Exposure to Motor-Vehicles. Journal of Environmental and Public Health. 2013;2013: 1-5.

[3] Allsop RE. Transport networks and their use: how real can modelling get? Philosophical Transactions of the Royal Society A: Mathematical, Physical and Engineering Sciences. 2008;2008(366): 1879-1892.

[4] Taniguchi E, Thompson RG, Yamada, T, van Duin R. City logistics: Network modelling and intelligent transport systems. Oxford, UK: Pergamon; 2001.

[5] Department for Transport. A New Deal for Transport: Better for Everyone. London, UK: 1998.

[6] Vanderbilt T. Traffic: Why we drive the way we do (and what it says about us). Information Design Journal. 2009;2009(17): 152-152.

[7] Downs A. Traffic: Why It's Getting Worse, What Government Can Do. Washington, USA: Brookings Policy Brief Series; 2004.

[8] Cervero R. Road Expansion, Urban Growth, and Induced Travel: A Path Analysis. Journal of the American Planning Association. 2003;2003(69): 145-163.

[9] Platzer MD, Harrison GJ. The U.S. automotive industry: National and state trends in manufacturing employment. Washington, DC: Congressional Research Service; 2009.

[10] Cavar I, Kavran Z, Jolic N. Intelligent Transportation System and Night Delivery Schemes for City Logistics. Computer Technology and Application. 2011;2011(2): 782-788.

[11] UITP. Public transport at the heart of the integrated urban mobility solution. Brussels, Belgium: UITP; 2016.

[12] Torjesen I. Cycling to work has substantial health benefits, study finds. BMJ. 2017;2017(357): j1944.

[13] Shaheen S. Commuter-Based Carsharing: Market Niche Potential. Transportation Research Record: Journal of the Transportation Research Board. 2001;2001(1760): 178-183.

[14] Ben-Elia E, Ettema D. Rewarding rush-hour avoidance: A study of commuters' travel behavior. Transportation Research Part A: Policy and Practice. 2011;2011(45): 567-582.

[15] Ettema D, Knockaert J, Verhoef E. Using incentives as traffic management tool: empirical results of the "peak avoidance" experiment. Transportation Letters. 2010;2010(2): 39-51.

[16] Su Q, Zhou L. Parking management, financial subsidies to alternatives to drive alone and commute mode choices in Seattle. Regional Science and Urban Economics. 2012;2012(42): 88-97.

[17] Semanjski I, Aguirre Lopez AJ, De Mol J, Gautama S.
Policy 2.0 Platform for Mobile Sensing and Incentivized Targeted Shifts in Mobility Behavior. Sensors. 2016;2016(16): 1035.

[18] Nakhjirkan S, Rafiei FM. An Integrated Multi-Echelon Supply Chain Network Design Considering Stochastic Demand: A Genetic Algorithm Based Solution. Promet - Traffic \& Transportation. 2017;29(4): 391-400.

[19] Black WR. Sustainable Transportation: Problems and Solutions. New York, USA: The Guilford Press; 2010.

[20] Arnott R, Small K. The economics of traffic congestion. American Scientist. 1994;1994(82): 446-455.

[21] Verhoef E, Nijkamp P, Rietveld P. Tradeable Permits: Their Potential in the Regulation of Road Transport Externalities. Environment and Planning $B$. 1997;1997(24): 527-548.

[22] Semanjski I, Bellens R, Gautama S, Witlox F. Integrating Big Data into a Sustainable Mobility Policy 2.0 Planning Support System. Sustainability. 2016;2016(8): 1142.

[23] Semanjski I, Gautama S. Crowdsourcing mobility insights - Reflection of attitude based segments on high resolution mobility behaviour data. Transportation Research Part C: Emerging Technologies. 2016;2016(71): 434-446.

[24] Taniguchi E. Concepts of City Logistics for Sustainable and Liveable Cities. Procedia - Social and Behavioral Sciences. 2014;2014(151): 310-317.

[25] Taniguchi E, Thompson RG, Yamada T. Recent Trends and Innovations in Modelling City Logistics. Procedia - Social and Behavioral Sciences. 2014;2014(125): 4-14.

[26] Anand N, Quak H, van Duin R, Tavasszy L. City Logistics Modeling Efforts: Trends and Gaps - A Review. Procedia - Social and Behavioral Sciences. 2012;2012(39): 101-115.

[27] Cochrane K, Saxe S, Roorda MJ, Shalaby A. Moving freight on public transit: Best practices, challenges, and opportunities. International Journal of Sustainable Transportation. 2016;2016(11): 120-132.

[28] Metro Report International. Freight tram to support electric car production. Surrey, UK: Metro Report International; 2017.

[29] ELTIS. Delivering goods by cargo tram in Amsterdam (Netherlands). Brussels, Belgium: ELTIS; 2015.

[30] Stojanovski T. The Revival of Buses as Bus Rapid Transit (BRT) in Urban and Regional Planning: Retrospect and Prospects. In: Proceedings of the European Transport Conference, 30 September - 02 October 2013, Frankfurt, Germany. ETC; 2013.

[31] Statbel. Statistiek - Statistics Belgium. Brussels, Belgium: be.STAT; 2017.

[32] Ghent University. Facts and figures. Ghent, Belgium: Ghent University; 2017.

[33] Nicholson H. Get on your bike in Belgium: The best way to see glorious Ghent? On two wheels. Daily mail. 2013;2013(11): 1-5.

[34] City of Ghent. Dashboard Gent. Ghent, Belgium: Stad Gent; 2017.

[35] De Lijn. Dagnet. Mechelen, Belgium: De Lijn; 2017.

[36] Bok J, Kwon Y. Comparable Measures of Accessibility to Public Transport Using the General Transit Feed Specification. Sustainability. 2016;2016(8): 224. 